\title{
KOMPOSISI BOTANI DAN PRODUKSI BAHAN KERING HIJAUAN PAKAN DI BAWAH NAUNGAN KELAPA SAWIT MILIK PT. MEDCO PAPUA HIJAU SELARAS MANOKWARI
}

\author{
Diana Sawen ${ }^{1}$, M. Junaidi ${ }^{2}$ dan Hengky Y. Yepasedanya ${ }^{3}$ \\ 1,2,3) Jurusan Peternakan, Fakultas Peternakan Universitas Papua Manokwari \\ e-mail: sawendian@yahoo.com.
}

\begin{abstract}
ABSTRAK
Studi ini dilakukan untuk mengetahui komposisi botani dan produksi bahan kering hijauan pakan yang terdapat di bawah naungan kelapa sawit. Penelitian dilakukan pada perkebunan kelapa sawit milik PT. Medco Papua Hijau Selaras Manokwari selama 2 bulan. Metode yang digunakan adalah metode deskriptif dengan teknik studi kasus. Analisis kadar air dilakukan di sub Laboratorium Agrostologi Fakultas Peternakan Universitas Papua. Hasil studi memperlihatkan bahwa spesies yang ditemukan berjumlah 22 spesies, produksi bahan kering hijauan pakan di bawah naungan kelapa sawit pada areal kelapa sawit umur 2 tahun adalah sebesar 0,36 ton/ha, pada umur 3 tahun sebesar 0,44 ton/ha dan pada areal kelapa sawit umur 4 tahun sebesar 0,45 ton/ha. Kandungan bahan kering hijauan pakan berkisar antara 5,85-20,80\%, dan kapasitas tampung untuk ketiga umur tanam kelapa sawit masing-masing sebesar 0,12 UT/ha/tahun (2 tahun), o,15 UT/ha/tahun (3 tahun) dan 0,15 UT/ha/tahun (umur tanam 4 tahun). Komposisi spesies hijauan dan kapasitas tampung areal ini belum ideal.
\end{abstract}

Kata kunci: komposisi botani, naungan kelapa sawit, produksi bahan kering

\section{BOTANIC COMPOSITION AND DRY MATTER PRODUCTION OF FORAGES UNDER PALM OIL SHADE OF PT MEDCO PAPUA HIJAU SELARAS MANOKWARI}

\begin{abstract}
This study was conducted to determine the botanic composition and dry matter production of forage found under the shade of oil palm. The research was conducted on an oil palm plantation owned by PT. Medco Papua Hijau Selaras Manokwari for 2 months. The method used is a descriptive method with a case study technique. The water content analysis was carried out in the Agrostology sub-laboratory of the Faculty of Animal Science, UNIPA. The results of the study showed that the number of species found was 22 species, the production of dry matter forage under the shade of oil palm in oil palm areas aged 2 years was 0.36 tons/ha, at 3 years old was 0.44 tons/ha and in the area of 4 years old oil palm is 0.45 ton/ha. Forage dry matter content ranged from $5.85-20.80 \%$, and the holding capacity for the three oil palm planting ages was $0.12 \mathrm{UT} / \mathrm{ha} /$ year (2 years), $0.15 \mathrm{UT} / \mathrm{ha} /$ year (3 years) and $0.15 \mathrm{UT} / \mathrm{ha} /$ year (4 years planting). The composition of forage species and the capacity of this area are not yet ideal.
\end{abstract}

Keywords: botanic composition, oil palm shade, dry matter production

\section{PENDAHULUAN}

Manokwari merupakan salah satu kabupaten di Provinsi Papua Barat yang memiliki total luas wilayah sebesar 115.363,50 km² (BPS Manokwari, 2016), dengan leading sektor pembangunan pertaniannya berupa pengembangan sub sektor peternakan dengan salah satu programnya adalah pengembangan usaha peternakan ruminansia. Pemerintah Provinsi Papua Barat khususnya Kabupaten Manokwari dengan gencar melakukan pengembangan usaha peternakan ini, yang hasil akhirnya diharapkan mampu memenuhi kebutuhan protein hewani asal daging sapi di wilayah provinsi dan kabupaten yang ada serta dapat membantu meningkatkan ekonomi masyarakat. Guna mencapai keberhasilan dalam usaha pengembangan peternakan ruminansia, ketersediaan pakan hijauan baik secara kuantitas, kualitas, dan kontinuitas sangatlah penting dan harus diperhatikan karena merupakan sumber pakan utama ternak ruminansia dan secara langsung turut mempengaruhi produktivitas ternak. Selain itu biaya pakan di dalam suatu usaha peternakan sangat tinggi yaitu mencapai $80 \%$ dari total biaya produksi.

Ternak ruminansia memerlukan pakan hijauan segar sebanyak 10\% dari bobot badannya setiap hari dimana proporsi hijauan pakan segar mencapai 80\% dari total ransum. Sedangkan jika berdasarkan bahan kering maka kebutuhan per hari sebesar $3 \%$ dari bo- 
bot badan. Namun dalam kenyataannya, ketersediaan hijauan pakan bagi ternak ruminansia baik secara kuantitas, kualitas, dan kontinuitas belum tercukupi. Selama ini para petani ternak hanya memperoleh hijauan pakan dari sisi-sisi jalan yang ditumbuhi rumput dan legum secara alami. Hal ini mengakibatkan terjadinya persaingan dan kompetisi dalam memperoleh hijauan pakan antara petani peternak.

Faktor lain yang turut mempengaruhi rendahnya ketersediaan hijauan pakan adalah terbatasnya tingkat penggunaan dan kepemilikan lahan. Oleh sebab itu untuk menjamin ketersediaan pakan bagi ternak ruminansia diperlukan sumber hijauan pakan alternatif yang diharapkan mampu memenuhi kebutuhan hijauan pakan bagi ternak ruminansia baik secara kuantitas, kualitas, dan kontinuitas. Salah satu hijauan pakan alternatif yang dapat dimanfaatkan adalah hijauan yang tumbuh di bawah naungan kelapa sawit dimana secara ekonomis, hijauan pakan tersebut belum termanfaatkan dengan baik. PT Perkebunan kelapa sawit ini sudah ada dan berkembang sejak tahun 2007 dengan luas wilayah atau lahan sebesar 13.850 hektar dengan pembagian lahan perkebunan kelapa sawit inti dan plasma.

Perkebunan ini berlokasi di kampung Sidey Jaya Distrik Sidey Kabupaten Manokwari. Selama ini potensi hijauan yang ada di bawah naungan kelapa sawit ini belum terdokumentasi sebagai potensi riset secara khusus dalam menunjang budidaya ternak ruminansia di sekitar areal ini. Padahal dalam kenyataannya, beberapa peternak juga sudah memanfaatkan potensi hijauan yang ada di sekitar areal perkebunan ini sebagai pakan bagi ternaknya. Kurangnya informasi tentang potensi hijauan pakan yang mencakup kelimpahan atau keragaman spesies dan produksi bahan keringnya sehingga dianggap perlu untuk dilakukannya penelitian ini.

Tujuan penelitian ini adalah untuk mengetahui seberapa besar keragaman spesies hijauan berdasarkan produksi berat segar dan produksi bahan kering hijauan pakan dari hijauan yang terdapat di bawah naungan kelapa sawit milik PT. Medco Papua Hijau Selaras Manokwari, serta mengestimasi kapasitas tampung pada areal tersebut.

\section{MATERI DAN METODE}

\section{Tempat dan Waktu Penelitian}

Penelitian ini dilaksanakan pada areal perkebunan kelapa sawit milik PT. Medco Papua Hijau Selaras Manokwari yang terletak di Kampung Sidey Jaya, Distrik Sidey, Kabupaten Manokwari. Analisis kadar air dilakukan di sub laboratorium Agrostologi Fakultas Peternakan UNIPA Manokwari. Penelitian berlangsung selama 2 bulan pada tahun 2016.

\section{Materi Penelitian}

Materi yang digunakan dalam penelitian meliputi: hijauan yang ada di lokasi perkebunan kelapa sawit, dan alkohol 70\% untuk pembuatan spesimen. Sedangkan peralatan yang digunakan yaitu kuadrat ukuran $1 \mathrm{~m} \times 1 \mathrm{~m}$, timbangan digital kapasitas $5 \mathrm{~kg}$ dan timbangan ohauss, kapas, koran bekas, plastik sampel, label, tali rafia, alumunium foil, oven, gegep, blender, kamera dan desikator serta alat tulis.

\section{Metode Penelitian}

Metode yang digunakan dalam penelitian ini merupakan metode deskriptif dengan studi kasus. Sebagai kasus adalah semua hijauan yang terdapat di bawah naungan kelapa sawit milik PT. Medco Papua Hijau Selaras Manokwari. Selanjutnya data pengamatan yang diperoleh, ditabulasi dan dideskripsikan dalam bentuk tabel dan grafik.

\section{Pengambilan Sampel atau Cuplikan}

Penentuan jumlah cuplikan, didasarkan pada syarat minimum pengambilan cuplikan hijauan yaitu untuk padang seluas 65 ha ditetapkan sebanyak 50 cluster atau 100 cuplikan (Susetyo, 1980). Pengambilan cuplikan, dilakukan dengan metode pelemparan kuadrat ukuran $1 \mathrm{~m} \times 1 \mathrm{~m}$ searah lorong tanam kelapa sawit. Selanjutnya dilakukan pemotongan dan penimbangan semua hijauan yang berada dalam kuadrat setinggi $10 \mathrm{~cm}$ dari permukaan tanah. Setiap jenis hijauan dipisahkan untuk dihitung jumlahnya dan ditimbang beratnya. Selanjutnya hijauan yang telah ditimbang, diambil sampelnya untuk analisis kadar air. Identifikasi dilakukan pada beberapa spesies hijauan yang tidak teridentifikasi di lapangan, yang telah terlebih dahulu dibuat spesimen dan selanjutnya dibawa ke Pusat Penelitian Keanekaragaman Hayati (PPKH) UNIPA. Manokwari.

Lokasi pengambilan cuplikan terbagi atas tiga areal perkebunan dengan umur tanam yang berbeda yaitu:

1. Kebun Plasma 1, Afdeling 1, Blok 1021043C seluas 26,74 ha dengan umur tanam 2 tahun

2. Kebun Plasma 1, Afdeling 1, Blok 0921043B seluas 29,58 ha dengan umur tanam 3 tahun, dan

3. Kebun Plasma 1, Afdeling 1, Blok 0821043A seluas 27,76 ha dengan umur tanam 4 tahun.

\section{HASIL DAN PEMBAHASAN}

\section{Keragaman Spesies}

Jenis tumbuhan atau spesies yang ada di bawah perkebaunan kelapa sawit, bervariasi antara perkebunan yang satu dengan yang lainnya sebagaimana terbagi dalam afdeling dan blok yang ada sesuai de- 
ngan manajemennya. Umur kelapa sawit ikut mempengaruhi keragaman tumbuhan atau spesies yang ada di bawah naungan kelapa sawitnya. Jenis atau spesies tumbuhan yang nampak yaitu rumput-rumputan, tumbuhan berdaun sempit, berdaun lebar yang juga dikelompokkan sebagai gulma dan ada juga leguminosa atau cover crop. Cover crop walaupun tumbuh alami dan liar namun bermanfaat untuk tanaman pokok karena memiliki kemampuan mengikat unsur nitrogen (N) dan berkontribusi juga untuk lingkungan di sekitarnya (Purwantari et al., 2015). Umumnya pada lahan-lahan kelapa sawit, jenis leguminosa penutup tanah ditanam saat sawit masih muda dan berfungsi sebagai penutup tanah yang berfungsi terutama untuk menjaga kelembaban tanah dan kesuburan tanah.

Berdasarkan observasi, komposisi botani hijauan yang ditemukan pada areal perkebunan kelapa sawit ini disajikan pada Tabel 1. Jumlah spesies hijauan yang ditemukan pada areal ini sebanyak 22 spesies, yang terbagi dalam 4 golongan yaitu rumput sebanyak 7 spesies $(31,82 \%)$, legume 1 spesies $(4,55 \%)$, hijauan lain 4 spesies $(18,18 \%)$ dan hijauan non pakan 10 spesies (45,45\%). Secara rinci dapat dilihat bahwa pada setiap areal penanaman kelapa sawit tersebut, ada terdapat spesies hijauan yang sama ataupun yang berbeda dan ada pula yang hanya ditemukan pada salah satu lokasi atau areal saja.

Tabel 1. Komposisi Botani Hijauan Berdasarkan Umur Tanam Kelapa Sawit

\begin{tabular}{|c|c|c|c|c|}
\hline \multirow[t]{2}{*}{ Spesies } & \multirow[t]{2}{*}{ Klasfikasi } & \multicolumn{3}{|c|}{$\begin{array}{c}\text { Umur Tanam } \\
\text { Kelapa Sawit (tahun) }\end{array}$} \\
\hline & & 2 & 3 & 4 \\
\hline Themeda arguens & $\mathrm{R}$ & $\sqrt{ }$ & - & $\sqrt{ }$ \\
\hline Paspalum conjugatum & $\mathrm{R}$ & $\sqrt{ }$ & $\sqrt{ }$ & $\sqrt{ }$ \\
\hline Echinochloa colonum & $\mathrm{R}$ & $\sqrt{ }$ & $\sqrt{ }$ & $\sqrt{ }$ \\
\hline Rhynocospora corymboza & $\mathrm{R}$ & $\sqrt{ }$ & $\sqrt{ }$ & - \\
\hline Digitaria decumbens & $\mathrm{R}$ & $\sqrt{ }$ & $\sqrt{ }$ & $\sqrt{ }$ \\
\hline Imperata cylindrica & $\mathrm{R}$ & $\sqrt{ }$ & $\sqrt{ }$ & - \\
\hline Cyperus rotundus & $\mathrm{HL}$ & - & - & $\sqrt{ }$ \\
\hline Eleusine indica & $\mathrm{R}$ & - & $\sqrt{ }$ & $\sqrt{ }$ \\
\hline Ipomoea batatas & $\mathrm{HL}$ & $\sqrt{ }$ & - & - \\
\hline Mucuna bracteata & $\mathrm{L}$ & $\sqrt{ }$ & $\sqrt{ }$ & $\sqrt{ }$ \\
\hline Micania micrantha & NP & $\sqrt{ }$ & $\sqrt{ }$ & $\sqrt{ }$ \\
\hline Sphenomeris chusana & NP & $\sqrt{ }$ & $\sqrt{ }$ & $\sqrt{ }$ \\
\hline Aster ageratoides & NP & $\sqrt{ }$ & $\sqrt{ }$ & - \\
\hline Callisia repens & $\mathrm{HL}$ & $\sqrt{ }$ & $\sqrt{ }$ & - \\
\hline Spigelia anthelmia & NP & $\sqrt{ }$ & - & - \\
\hline Ageratum conyzoides & NP & $\sqrt{ }$ & $\sqrt{ }$ & $\sqrt{ }$ \\
\hline Bidens pilosa & $\mathrm{HL}$ & $\sqrt{ }$ & - & - \\
\hline Cyclosorus aridus & NP & $\sqrt{ }$ & $\sqrt{ }$ & $\sqrt{ }$ \\
\hline Borreria alata & NP & - & $\sqrt{ }$ & - \\
\hline Borreria leavis & NP & - & $\sqrt{ }$ & $\sqrt{ }$ \\
\hline Euphorbia hirta L & NP & - & - & $\sqrt{ }$ \\
\hline Neophorolepis biserata & NP & - & $\sqrt{ }$ & - \\
\hline
\end{tabular}

Keterangan: R=rumput; L=legum; $\mathrm{HL}=$ hijauan lain; $\mathrm{NP}=$ non pakan
Tabel 1 memperlihatkan bahwa pada umur tanaman kelapa sawit yang berbeda memiliki jenis tumbuhan atau spesies hijauan yang berbeda pula, dan yang mendominasi adalah jenis hijauan non pakan dan rumput. Jumlah spesies hijauan per lokasi yaitu lokasi umur tanam kelapa sawit 2 dan 3 tahun masing-masing sebesar 16 spesies dan 13 spesies untuk umur tanam 4 tahun. Hal ini karena semua spesies hijauannya tumbuh secara alami dan belum ada pengelolaannya oleh pihak perusahaan perkebunan kelapa sawit. Banyaknya spesies hijauan yang tumbuh di suatu lahan dapat disebabkan karena faktor manajemen yaitu manusia seperti kurangnya perawatan atau pemeliharaan (Infitria dan Khalil, 2012).

Hasil penelitian Daru et al. (2014), mendapatkan bahwa jenis tanaman yang tumbuh di bawah kelapa sawit rakyat kecamatan Samboja Kabupaten Kutai Kartanegara, dengan umur tanam yang berbeda ( 3 tahun dan 6 tahun) menghasilkan proporsi yang berbeda pula. Beberapa spesies hijauan pakan yang mendominasi areal perkebunan kelapa sawit antara lain, untuk umur 3 tahun yaitu Paspalum conjugatum (45,54\%), Mikania micranta (9,93\%) dan Ottochloa nodosa (7,89\%). Sedangkan umur 6 tahun didominasi oleh Ottochloa nodosa (33,89\%), Melastoma malabatrichum (28,23\%) dan Paspalum urvillei $(8,37 \%)$. Namun proporsi ini cukup ideal karena proporsi hijauan pakan telah memenuhi kriteria ideal untuk suatu lahan atau areal padang penggambalaan bagi ternak. Selain itu, Ramdani et al. (2017), menyebutkan bahwa jenis hijauan yang ditemukan di perkebunan sawit secara keseluruhan di Kecamatan Mandau Kabupaten Bengkalis adalah Paspalum conjugatum, Panicum repens, Ageratum conyzoides, Asystasia intrusa dan Melastoma malabatcrichum. Ditemukan juga bahwa pada semua (7) desa lokasi penelitian, pada perkebunan sawit yang berumur 3 tahun memiliki jenis hijauan yang lebih beragam dibandingkan dengan umur 9 dan 15 tahun. Selain itu Prawiradiputra (2011) menyatakan bahwa di perkebunan sawit Lebak Banten didominasi oleh Paspalum conjugatum (91,50\%). Spesies native yang sering ditemukan pada lahan perkebunan sawit, kelapa dan karet yaitu Axonopus compressus, Ottocholoa nodosa, Ageratum conizoides, Mikania micranta dan Asystasia gangetica (Dianita, 2012).

Berdasarkan kategorinya, jenis leguminosa yang ditemukan hanya 1 spesies yaitu Mucuna bracteata. Hasil penelitian Farizaldi (2011) pada lahan kelapa sawit umur 3, 5, dan 8 tahun di Jambi menemukan bahwa semakin meningkat umur tanaman kelapa sawit maka dominasi rumput semakin berkurang. Hal ini berkaitan dengan proses fotosintesis (Sawen, 2012) pada tanaman yaitu pencahayaan pada naungan kelapa sawit. Semakin terbukanya tajuk pohon kelapa 
sawit justru menghalangi penetrasi cahaya matahari bagi tanaman di bawahnya (Kurniawan et al., 2005; Firman, 2003; Akbar, et al., 2021). Selain itu, Akbar et al. (2021), berdasarkan kategori umur tanaman sawit di Kabupaten Aceh Timur ditemukan bahwa spesies hijauan paling banyak ditemukan pada area perkebunan TBM (tanaman belum menghasilkan) dan jumlah paling sedikit atau rendah ditemukan pada area tanaman sawit tua. Hal ini ditunjukkan dengan nilai INP (indeks nilai penting) spesies yang tinggi, seperti INP tertinggi $(14,29)$ terdapat pada TBM dengan spesies Asystasia gangetica, Panicum repens dan Paspalum conjugatum.

Berdasarkan komposisi botani, terlihat juga bahwa komposisi hijauan non pakan memiliki dominansi yang tinggi $(56,25 \%)$ pada ketiga areal perkebunan kelapa sawit tersebut (Tabel 1), dan hijauan pakan sebesar 43,75\% dengan proporsi rumput sebesar $37,50 \%$ dan legum $6,25 \%$. Hasil ini sama dengan hasil penelitian Dominanto dan Tirajoh (2017), yaitu jenis hijauan lain atau hijauan non pakan yang mendominasi lahan di bawah naungan sawit di Kecamatan Prafi Kabupaten Manokwari, yaitu sebesar $55,56 \%$, rumput $25,92 \%$ dan legum $18,52 \%$. Dengan demikian dapat dikatakan bahwa komposisi atau proporsi ideal untuk suatu areal padangan atau padang penggembalaan ternak pada areal perkebunan ini, belum ideal sebagaimana rekomendasi Susetyo (1980) bahwa komposisinya idealnya: 60\% rumput dan 40\% legum atau proporsinya $3: 2$ (McIlroy, 1977).

Pada prinsipnya keragaman spesies dan komposisi botani suatu areal atau padang penggembalaan memiliki kesamaan dengan indikator utama proporsi atau perbandingan hijauan pakan yang ada atau tersedia. Hal ini nampak pada hasil riset yang dilakukan oleh Juanidi dan Sawen (2010) bahwa komposisi spesies pada penggembalaan alami di Kabupaten Yapen memiliki proporsi hijauan pakan $46,33 \%$ dan 53,67\% hijauan non pakan. Sudah tentu bahwa padang penggembalaan ini belum memenuhi syarat ideal yang direkomendasikan sehingga perlu dilakukan perbaikan sehingga dapat menghasilkan produktivitas hijauan pakan yang lebih baik.

\section{Produksi Bahan Kering}

Pengukuran produksi hijauan dapat dilakukan dengan cara pengukuran terhadap bahan kering dan produksi hijauan segar. Karena di dalam bahan kering terdapat bahan organik yang terdiri atas protein, karbohidrat, dan lemak (Soetanto dan Subagyo, 1988). Kandungan bahan kering suatu spesies hijauan pakan diartikan sebagai selisih berat hijauan segar dengan kadar air yang terdapat di dalamnya, dimana presentase kadar airnya sangat dipengaruhi oleh spesies dan umur tanaman tersebut (Tillman et al., 1991).
Kandungan bahan kering tertinggi (Tabel 2), diperoleh dari spesies Imperata cylindrica yaitu 20,80\% dan yang terendah adalah Themeda arguens 5,85\%. Produksi bahan kering dari suatu hijauan maupun hijauan pakan sangat dipengaruhi oleh produksi bahan segar dan persentase kandungan bahan kering dari hijauan tersebut.

Tabel 2. Kandungan dan Produksi Bahan Kering Spesies Hijauan

\begin{tabular}{|c|c|c|c|c|}
\hline \multirow[t]{2}{*}{ Spesies } & \multirow[t]{2}{*}{$\begin{array}{c}\text { Kandungan } \\
\text { BK (\%) }\end{array}$} & \multicolumn{3}{|c|}{$\begin{array}{l}\text { Produksi Bahan Kering } \\
\text { (g/m) / Umur tanam } \\
\text { kelapa sawit (tahun) }\end{array}$} \\
\hline & & 2 & 3 & 4 \\
\hline Themeda arguens & 5,85 & 2,04 & - & 0,18 \\
\hline Paspalum conjugatum & 12,58 & 6,94 & 20,61 & 7,07 \\
\hline Echinochloa colonum & 13,48 & 2,26 & 0,67 & 2,80 \\
\hline Rhynocospora corymboza & 16,25 & 1,87 & 4,92 & - \\
\hline Digitaria decumbens & 17,96 & 5,27 & 6,60 & 16,74 \\
\hline Imperata cylindrica & 20,80 & 0,66 & 0,52 & - \\
\hline Cyperus rotundus & 15,20 & - & - & 0,47 \\
\hline Eleusine indica & 14,25 & - & 1,55 & 4,85 \\
\hline Ipomoea batatas & 9,96 & 0,23 & - & - \\
\hline Mucuna bracteata & 9,65 & 16,80 & 9,27 & 12,71 \\
\hline Micania micrantha & - & 42,21 & 13,41 & 8,51 \\
\hline Sphenomeris chusana & - & 0,63 & 0,94 & 0,56 \\
\hline Aster ageratoides & - & 0,25 & 0,56 & - \\
\hline Callisia repens & - & 0,61 & 0,08 & - \\
\hline Spigelia anthelmia & - & 2,68 & - & - \\
\hline Ageratum conyzoides & - & 2,57 & 1,48 & 2,14 \\
\hline Bidens pilosa & - & 0,95 & - & - \\
\hline Cyclosorus aridus & - & 0,38 & 0,68 & 0,02 \\
\hline Borreria alata & - & - & 0,20 & - \\
\hline Borreria leavis & - & - & 0,16 & 0,66 \\
\hline Euphorbia hirta L & - & - & $\mathrm{O}, \mathrm{OO}$ & 1,08 \\
\hline Neophorolepis biserata & - & - & 0,72 & - \\
\hline
\end{tabular}

Tabel 2 menggambarkan bahwa rataan produksi bahan kering dari hijauan yang terdapat di bawah naungan kelapa sawit yang berumur lebih tua cenderung menurun jika dibandingkan dengan produksi bahan kering dari areal dengan umur tanam umur yang lebih muda. Rataan produksi bahan kering hijauan pada areal perkebunan dengan umur tanam berbeda berturut-turut adalah: areal perkebunan umur 2 tahun sebesar $86,35 \mathrm{gram} / \mathrm{m}^{2}$, areal perkebunan umur 3 tahun sebesar $62,37 \mathrm{gram} / \mathrm{m}^{2}$ dan areal perkebunan umur 4 tahun sebesar $57,82 \mathrm{gram} / \mathrm{m}^{2}$. Sedangkan untuk spesies hijauan pakan yaitu umur 2 tahun menghasilkan produksi BK sebesar 36,07 gram $/ \mathrm{m}^{2}$, umur 3 tahun sebesar 44,14 gram $/ \mathrm{m}^{2}$ dan umur 4 tahun sebesar 44,82 gram $/ \mathrm{m}^{2}$ atau masing-masing dengan presentasi 41,77\% (umur 2 tahun), 70,77\% (umur 3 tahun) dan 77,52\% (umur 4 tahun).

Hasil penelitian Farizaldi (2011) menemukan bahwa pada umur tanaman kelapa sawit yang semakin tua menghasilkan produksi bahan kering hijauan pakan yang lebih rendah dan sebaliknya. Kelapa sawit 
umur 3 tahun menghasilkan produksi bahan kering hijauan pakan 0,64 ton/ha, umur 5 tahun sebesar 0,51 ton/ha dan umur kelapa sawit 8 tahun sebesar o,32 ton/ha. Penyebab rendahnya produksi bahan kering hijauan pakan disebabkan karena semakin bertambahnya umur tanaman maka ukuran kanopi atau tajuk tanaman bertambah besar sehingga mengurangi cahaya yang diterima oleh hijauan yang tumbuh di bawahnya. Akibatnya mempengaruhi pertumbuhan hijauan pakan sehingga tidak optimal.

Menurut Tillman et al. (1991), kandungan bahan kering suatu spesies hijauan pakan diartikan sebagai selisih berat hijauan segar dengan kadar air yang terdapat di dalamnya, dimana presentase kadar airnya sangat dipengaruhi oleh jumlah intensitas cahaya matahari yang diterima, kandungan unsur hara, spesies tanaman serta umur tanaman. Selanjutnya Soetanto dan Subagyo (1988), mengemukakan bahwa produksi dari bahan kering suatu spesies hijauan sangat dipengaruhi oleh lama interval dan frekuensi pemotongan, pemupukan, umur tanaman, jenis tanaman, tatalaksana pemeliharaan serta imbangan daun dan batang.

\section{Estimasi Kapasitas Tampung}

Kapasitas tamping merupakan cerminan produktivitas dari suatu areal atau padang penggembalaan. Hasil estimasi kapasitas tampung berdasarkan produksi bahan kering hijauan pada areal di bawah naungan kelapa sawit dengan umur tanam yang berbeda disajikan pada Tabel 3 .

Tabel 3. Estimasi Kapasitas Tampung

\begin{tabular}{|c|c|c|c|}
\hline \multirow{2}{*}{ Uraian Parameter } & \multicolumn{3}{|c|}{ Umur Kelapa Sawit } \\
\hline & 2 Tahun & 3 Tahun & 4 Tahun \\
\hline $\begin{array}{l}\text { Produksi BK hijauan pakan per } \\
m^{2}(g)\end{array}$ & 36,07 & 44,14 & 44,82 \\
\hline Produksi BK per hektar (kg) & 360,7 & 441,4 & 448,2 \\
\hline Produksi hijauan tersedia & 90,17 & 110,35 & 112,05 \\
\hline $\begin{array}{l}\text { Kapasitas tampung } \\
\text { (UT/ha/tahun) }\end{array}$ & 0,121 & 0,148 & 0,150 \\
\hline $\begin{array}{l}\text { Kapasitas tampung lahan sawit } \\
\text { (UT/ha/tahun) }\end{array}$ & 3,24 & 4,38 & 4,18 \\
\hline
\end{tabular}

Tabel 3 mendeskripsikan bahwa berdasarkan jumlah ketersediaan bahan kering hijauan pakan maka, areal perkebunan umur 2 tahun mampu menampung o,12 UT/ha/tahun, areal perkebunan umur 3 tahun mampu menampung 0,15 UT/ha/tahun dan areal perkebunan umur 4 tahun mampu menampung 0,15 UT/ha/tahun. Hasil estimasi ini menunjukkan bahwa nilai kapasitas tampung pada areal perkebunan kelapa sawit ini masih tergolong rendah. Hal ini didasarkan pada pernyataan Reksohadiprodjo (1985), bahwa suatu padangan dikatakan baik apabila mampu menampung 2,5 UT/ha/tahun. Hasil ini berbeda dan berbanding terbalik dengan Farizaldi (2011), dimana kapasitas tampung untuk areal umur tanaman kelapa sawit 3 tahun sebesar 0,22 ST/ha/tahun, untuk umur tanaman 5 tahun sebesar 0,18 ST/ha/tahun dan umur 8 tahun sebesar 0,04 ST/ha/tahun. Namun sejalan juga dengan komposisi botani yang dihasilkan yaitu pada umur tanam yang semakin tua, komposisi botaninya lebih tinggi karena banyak ditemukan spesies legum sebagai penutup tanah.

Rendahnya kemampuan atau kapasitas tampung ini sangat dipengaruhi oleh jumlah ketersediaan hijauan pakan di areal tersebut. Rendahnya produksi hijauan yang tumbuh pada areal di bawah naungan kelapa sawit disebabkan karena umumnya hijauan yang tumbuh hanya terdiri dari jenis-jenis hijauan lokal dimana hijauan tersebut tumbuh secara alami tanpa campur tangan manusia. Menurut AAK (1993), produktivitas hijauan makanan ternak pada suatu padangan sangat mempengaruhi tinggi rendahnya kapasitas tampung dari padangan tersebut. Hal ini karena produktivitas hijauan makanan itu sendiri sangat dipengaruhi oleh faktor genetik dan faktor lingkungan yang meliputi keadaan tanah, iklim, serta perlakuan manusia (managemen).

\section{SIMPULAN DAN SARAN}

Jumlah spesies hijauan yang ditemukan pada areal perkebunan kelapa sawit berjumlah 22 spesies dengan komposisi rumput 8 spesies, legum 1 spesies, hijauan lain 3 spesies dan hijauan non pakan 10 spesies. Produksi bahan kering hijauan pakan pada areal perkebunan kelapa sawit umur 2 tahun sebesar 0,36 ton/ha, umur 3 tahun sebesar 0,44 ton/ha dan umur 4 tahun, sebesar 0,45 ton/ha. Sedangkan kapasitas tampungnya yaitu pada aeral perkebunan kelapa sawit umur 2 tahun sebesar 0,12 UT/ha/tahun, umur 3 tahun sebesar 0,15 UT/ha/tahun dan umur 4 tahun sebesar 0,15 UT/ha/tahun, sehingga masih dikategorikan dalam golongan kapasitas tampung yang rendah.

\section{UCAPAN TERIMA KASIH}

Disampaikan kepada pimpinan dan seluruh staf pada perkebunan kelapa sawit milik PT. Medco Papua Hijau Selaras Manokwari yang telah memberikan ijin dan kesempatan melakukan penelitian.

\section{DAFTAR PUSTAKA}

Akbar, F., N.R. Kumalasari dan L. Abdullah. 2021. Evaluasi Potensi Keragaman Hijauan Penutup Tanah di Perkebunan Kelapa Sawit Rakyat Kabupaten Aceh Timur Provinsi Aceh. Jurnal 
Ilmu Lingkungan Vol. 19(1):163-169. ISSN:18298907.

Aksi Agraris Kanisius., 1993. Hijauan Makanan Ternak Potong dan Kerja. Kanisius. Yogyakarta.

BPS Manokwari. 2016. Kabupaten Manokwari Dalam Angka.Badan Pusat Statistik Kabupaten Manokwari.

Daru, T. P., A. Yulianti dan E. Widodo. 2014. Potensi Hijauan di Perkebunan Kelapa Sawit sebagai Pakan Sapi Potong di Kabupaten Kutai Kartanegara. Jurnal Pastura Vol. 3(2):94-98. ISSN:2088-818X.

Dianita, R. 2012. Keragaman Fungsi Tanaman Pakan dalam Sistem Perkebunan. Jurnal Pastura Vol. 2 (2):66-69. ISSN: 2088-818X.

Dominanto, G. P. dan S. Tirajoh. 2017. Potensi dan Kendala Integrasi Sapi-Sawit Di Kecamatan Prafi Kabupaten Manokwari Papua Barat. Prosiding Seminar Nasional Balai Besar Pengkajian dan Pengembangan Teknologi Pertanian (BPTP) Maluku. Hal 718-722. http://repository. pertanian.go.id.

Farizaldi. 2011. Produktivitas Hijauan Makanan Ternak Pada Lahan Perkebunan Kelapa Sawit Berbagai Kelompok Umur di PTPN 6 Kabupaten Batanghari Propinsi Jambi, Jurnal Imiah Ilmuilmu Peternakan, 14(2), pp 68-73.

Firman. 2003. Studi Tentang Komposisi Botanis, Produksi Hijauan dan Proyeksi Kapasitas Tampung Lahan di bawah Naungan Perkebunan Kelapa Sawit Milik PT. PN II Tanjung Marowa Kebun Arso Jayapura. Skripsi. Fakultas Peternakan, Perikanan dan Ilmu Kelautan. Universitas Negeri Papua. Manokwari.

Infitria dan Khalil. 2012. Suatu Studi Produksi dan Kualitas Hijauan di Lahan Padang Rumput UPT Peternakan Universitas Andalas. Bulletin Makanan Ternak, 101(1), 25-33.

Junaidi, M. dan D. Sawen. 2010. Keragaman Botanis dan Kapasitas Tampung Padang Penggembalaan Alami di Kabupaten Yapen. Jurnal Ilmu Peternakan dan Veteriner, 5(2): 92-97.
Kurniawan W., Abdullah L dan Setiana M. A., 2005. Produksi dan Kualitas Rumput Brachiaria humidicola (Rend.) Sch, Digitaria decumbens Stent dan Stenotaphrum secundatum (Walter) O. Kunt. Di Bawah Naungan Sengon, Karet dan Kelapa Sawit. Departemen Ilmu Nutrisi dan Teknologi Pakan, Fakultas Peternakan. IPB. Bogor.

McIlroy, R.J. 1977. Pengantar Budidaya Padang Rumput Tropika. Pradnya Paramitha, Jakarta.

Purwantari, N. D., B. Tiesnamurti, dan Y. Adinata. 2015. Ketersediaan Sumber Hijauan di Bawah Perkebunan Kelapa Sawit untuk Pengembalaan Sapi. Wartazoa, 25(1), 47-54. doi:http://dx.doi. org/10.12334/wartazoa.v25i1.1128

Prawiradiputra, B. R. 2011. Komposisi jenis hijauan pakan kerbau di luar dan di dalam Perkebunan Kelapa sawit Kabupaten Lebak Banten. Prosiding Seminar dan Lokakarya Nasional Kerbau. Balai Penelitian Ternak Ciawi, Bogor.

Ramdani, D., L. Abdullah, dan N. R. Kumalasari. 2017. Analisis Potensi Hijauan Lokal pada Sistem Integrasi Sawit dengan Ternak Ruminansia di Kecamatan Mandau Kabupaten Bengkalis provinsi Riau. Buletin Makanan Ternak, Vol. 104 (1): 1-8. ISSN: 0216-065X.

Reksohadiprodjo, S. 1985. Produksi Hijauan Makanan Ternak. BPFE. UGM. Yogyakarta.

Sawen, D. 2012. Pertumbuhan Rumput Gajah (Pennisetum perpureum) dan Benggala (Panicum maximum) Akibat Perbedaan Intensitas Cahaya. Jurnal Ilmu Tanaman dan Ternak. Vol. 2: 17-20.

Soetanto, H dan Subagyo I. 1988. Landasan Agrostologi. NUFFIC - Universitas Brawijaya. Malang.

Susetyo, S. 1980. Padang Penggembalaan. Departemen Ilmu Makanan Ternak. IPB. Bogor.

Tillman, A. D., Hartadi H., Reksohadiprodjo S., Prawiro K.S dan Lebdosoekojo S. 1991. Ilmu Makanan Ternak Dasar. Cetakan ke 6. Gadjah Mada University Press. Yogyakarta. 